\title{
Relationships between allozyme heterozygosity and gut morphology in Apodemus agrarius
}

\author{
Anetta BORKOWSKA and Mirosław RATKIEWICZ
}

\begin{abstract}
Borkowska A. and Ratkiewicz M. 1996. Relationships between allozyme heterozygosity and gut morphology in Apodemus agrarius. Acta Theriologica 41: 367-374.

We studied enzyme polymorphisms in a striped field mouse Apodemus agrarius (Pallas, 1771) population from NE Poland and the relationships between heterozygosity and length and mass of the digestive tract organs, and the mucosal surface area of the small intestine. Most of 38 loci studied were found monomorphic (proportion of polymorphic loci $\bar{P}=0.053$, observed average heterozygosity $\bar{H}_{o}=0.021$ ). Heterozygotes were found for Acy, Pgm-1, Mdh-2, Est-D, Pgi, Sdh and Trf. Heterozygous males had longer large intestines and ceca and smaller liver wet mass than their homozygous conterparts. However, in females there were no significant interactions between heterozygosity and gut parameters. We suggest that the low level of polymorphism, the particular set of the loci examined and sex have an effect on detection of differences between heterozygous and homozygous individuals.

Institute of Biology, Warsaw University, Branch in Białystok, ul. Świerkowa 20B, 15-950 Białystok, Poland

Key words: Apodemus agrarius, heterozygosity, gut morphology
\end{abstract}

\section{Introduction}

Allozyme heterozygosity is correlated with many physiological and behavioural attributes of animals including liver glycogen mobilisation (Leigh Brown 1977), fat utilization (Cothran et al. 1987), oxygen consumption (Mitton et al. 1986), and exploratory behaviour (Garten 1977). A positive association between genic variability and fitness has also been observed (Teska et al. 1990). The authors reported that under varying degrees of dietary stress more heterozygous mice (Peromyscus polionotus) utilized food and maintained body weight better than their less heterozygous conterparts.

Relationships between protein heterozygosity and a number of attributes of individuals have been tested so far for species characterized by high genetic variability (Garten 1977, Teska et al. 1990). The striped field mouse Apodemus agrarius (Pallas, 1771) is characterized by a large number of species-specific alleles but the extent of allele polymorphism is not very high (Britton-Davidian et al. 1991, Hartl et al. 1992). On the other hand, A. agrarius has the enormous ecological 
and physiological plasticity which appears in the ability to replace highly nutritive seeds and animal food by low-quality green parts of plants. The field mouse opportunistically utilizes energy-rich food such as seeds, fruits and invertebrates (Holišova 1967). However, it can also feed mainly on green food (Gębczyńska et al. 1987, 1989).

Teska et al. (1990) observed that Peromyscus polionotus with high heterozygosity maintained the same feeding efficiency with changing diet quality while in those with lower heterozygosity feeding efficiency decreased with quality of the diet. The indicators of changing diet quality may be dimensions of the alimentary tract compartments (Green and Millar 1987). Therefore, it seems interesting to investigate relationships between heterozygosity and gut parameters. The main purpose of the present study was to determine whether the length and mass of the gut compartments are related to heterozygosity in spite of a low level of enzyme polymorphism in A. agrarius.

\section{Material and methods}

Ninety four striped field mice were live-trapped in the vicinity of Białystok (NE Poland, $23^{\circ} 07^{\prime} \mathrm{E}$, $53^{\circ} 18^{\prime} \mathrm{N}$ ) in shrubs at the edges of the fields and allotments in 1992 and 1993 . The mice were brought into laboratory, killed and dissected. Their age (adults - mice weighting at least $17 \mathrm{~g}$ ), sex and reproductive status were determined (Table 1). Immediately, gastrointestinal tract organs were removed and separated into stomach (from the cardiac to pyloric sphincter), small intestine (from pyloric sphincter to ileocolical valve), cecum and large intestine (from ileocolical valve to anus). Length of small intestine, cecum and large intestine (with contents) was measured to $0.1 \mathrm{~cm}$ using a ruler. Mesenteries were removed and organs were held to their maximum unstretched length on glass plate with poured normal saline solution. Wet mass without contents of stomach, cecum and the large intestine, wet mass with contents of the small intestine and liver wet mass were recorded to $0.001 \mathrm{~g}$. The mucosal surface area of the small intestine was considered equal to the mean surface area of the villus $\times$ total number of villi + the mucosal surface area which was not covered by villi (for details of the method see Borkowska 1995). All measurements were done by the first author to minimize variability.

Table 1. Number of individuals in two classes of allozyme heterozygosity in Apodemus agrarius (NE Poland). Ho - individuals homozygous at all the loci studied, $\mathrm{Ht}$ - individuals heterozygous at one or more loci studied, ad - adult, juv - juvenile, "+" - sexually active animals, "-" - sexually inactive animals, $*^{*}$ - all sexually active females were pragnant or lactating, ns - not significant difference.

\begin{tabular}{|c|c|c|c|c|c|c|c|}
\hline & \multicolumn{2}{|c|}{ Females } & \multicolumn{2}{|c|}{ Males } & \multirow{2}{*}{$\chi^{2}$} & \multirow{2}{*}{$\mathrm{df}$} & \multirow{2}{*}{$p$} \\
\hline & Ho & $\mathrm{Ht}$ & Ho & $\mathrm{Ht}$ & & & \\
\hline$n$ & 24 & 22 & 21 & 27 & 0.67 & 1 & $\mathrm{~ns}$ \\
\hline ad & 14 & 13 & 13 & 17 & 0.41 & 1 & $\mathrm{~ns}$ \\
\hline adt+ & $6^{*}$ & $10^{*}$ & 8 & 12 & 0.02 & 1 & $\mathrm{~ns}$ \\
\hline ad- & 8 & 3 & 5 & 5 & 1.15 & 1 & $\mathrm{~ns}$ \\
\hline juv & 10 & 9 & 8 & 10 & 0.25 & 1 & $\mathrm{~ns}$ \\
\hline
\end{tabular}


Homogenates for electrophoresis were obtained from blood, kidney and liver tissue by crushing in phosphate buffer $(0.01 \mathrm{M}, \mathrm{pH} 7.5)$ and centrifugation at $12000 \mathrm{rpm}$ for $15 \mathrm{~min}$ at $4^{\circ} \mathrm{C}$. Horizontal starch gel electrophoresis was performed according to Selander et al. (1971), Harris and Hopkinson (1976), and Quavi and Kit (1980). In each specimen a total of 39 protein loci were examined. A locus was considered polymorphic if the frequency of the most common allele did not exceed 0.95 . Alleles at polymorphic loci were designated alphabetically with increasing anodal migration of the corresponding allozymes. Observed average heterozygosity $\left(\bar{H}_{0}\right)$ was estimated after Nei (1978). Deviations of genotypic proportions from Hardy-Weinberg expectations were tested using the $\chi^{2}$ goodness-of-fit test.

Mice were grouped into two classes of allozyme heterozygosity for data analysis: (1) Ho individuals homozygous at all the loci studied and (2) $\mathrm{Ht}$ - individuals heterozygous at one or more loci studied (Table 1).

Analysis of covariance (ANCOVA) was used to compare length and wet mass of gastrointestinal tract organs, serosal and mucosal surface area of the small intestine between $\mathrm{Ho}$ and $\mathrm{Ht}$ individuals. Because the gut parameters studied were closely related to body mass (all correlation coefficients $>0.70, p<0.001$ ), total body mass was used as a covariate. There were no significant differences $(p>0.05$ in ANCOVA) in most of the gut parameters between adults and juveniles and significant differences $(p<0.05$ in ANCOVA) were found between sexes, therefore, dependent variables were analysed separately for males and females. Interactions between the covariate (body mass) and the main effect (heterozygosity) were also tested. When ANCOVA yielded significant interactions (body mass $\times$ heterozygosity) we used stepwise multiple regression analysis (Zar 1984) to remove possible effects of body mass on those organs lengths and masses. Distribution of $\mathrm{Ho}$ and $\mathrm{Ht}$ individuals in age and sexual activity groups between sexes was tested using $\chi^{2}$-test. All means are presented \pm 1 standard error (SE). Differences with $p<0.05$ were considered statistically significant.

\section{Results}

\section{Allozyme polymorphisms}

Most of the loci studied were monomorphic (see Appendix). Single heterozygotes were found at Pgi, Sdh and Trf. Three other loci showed more variation: $6 \mathrm{AB}$ heterozygotes at Pgm-1, $9 \mathrm{AB}$ heterozygotes at $M d h-2,4 \mathrm{AB}$ and $16 \mathrm{BC}$ heterozygotes at Est-D were recorded. Only the Acy locus was higly polymorphic and we found all possible genotypes (42 AA, $36 \mathrm{AB}, 16 \mathrm{BB}$ ). Peptidase- 2 was found polymorphic, too. However, because of the ambigious patterns on zymograms the variation for this locus was not analysed. Thus, 38 loci were used for further analysis.

We found 45 individuals homozygous at all the loci studied (Ho class) and 33 mice were heterozygous at one locus, 12 mice were heterozygous at two loci, and 4 mice were heterozygous at three loci. For further analysis all heterozygous individuals were grouped into one class $(\mathrm{Ht})$. There were no significant differences in number of $\mathrm{Ho}$ and $\mathrm{Ht}$ individuals between sexes in sexually active and inactive adults and in juveniles (Table 1).

Proportion of polymorphic loci $(\bar{P})$ was 0.053 (0.05 level), observed average heterozygosity $H_{o}$ was 0.021 . No significant deviations from the Hardy-Weinberg equilibrium were found at any locus $(p>0.05)$. 


\section{Morphological parameters and heterozygosity}

Total body mass did not vary significantly with heterozygosity both in males $\left(\mathrm{F}_{[1,45]}=0.04, \mathrm{~ns}\right)$ and females $\left(\mathrm{F}_{[1,44]}=1.52, \mathrm{~ns}\right)$. Ho and $\mathrm{Ht}$ males weighted 18.9 $\pm 1.3 \mathrm{~g}$ and $19.2 \pm 1.2 \mathrm{~g}$, respectively, and Ho and Ht females showed a mean weight of $17.9 \pm 1.4 \mathrm{~g}$ and $20.7 \pm 1.9 \mathrm{~g}$, respectively.

Analysis of covariance revealed that cecum length was greater in $\mathrm{Ht}$ males than Ho males $\left(\mathrm{F}_{[1,46]}=4.64, p<0.05\right.$; Fig. 1$)$. The small intestine length did not differ beween Ho and $\mathrm{Ht}$ males $\left(\mathrm{F}_{[1,46]}=0.68\right.$, ns; Fig. 1). However, for large intestine length there was a significant interaction between body mass (covariate) and heterozygosity. Multiple regression proved that both body mass $\left(R^{2}=0.32, p\right.$ $<0.0001)$ and heterozygosity $\left(R^{2}=0.08, p<0.05\right)$ were significant variables for the large intestine length in males (Fig. 1).

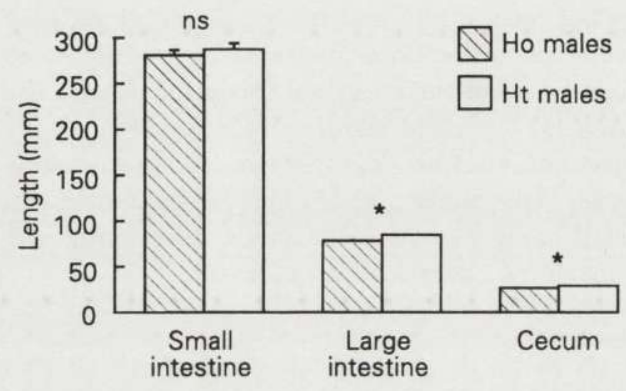

Fig. 1. Small intestine length, large intestine length and cecum length of Apodemus agrarius males. Ho - individuals homozygous at all the loci studied, $\mathrm{Ht}$ - individuals heterozygous at one or more loci studied. The bars above each value represent one standard error. The bars are omitted when they are smaller than the histogram line thickness. Significance levels are given above the bars: in ANCOVA (small intestine and cecum) and in stepwise multiple regression (large intestine); ${ }^{*}-p<0.05, \mathrm{~ns}-$ not significant difference.

In females there was no significant effect of heterozygosity on cecum length $\left(\mathrm{F}_{[1,44]}=0.71, \mathrm{~ns}\right)$. However, interactions between body mass and heterozygosity were significant for small intestine length $\left(\mathrm{F}_{[1,44]}=8.16, p<0.01\right)$ and large intestine length $\left(\mathrm{F}_{[1,44]}=5.69, p<0.05\right)$ in females. The significant independent variable was body mass, which accounted for $63 \%$ and $65 \%$ of their variations in the small intestine length and the large intestine length, respectively.

Stomach wet mass, small intestine wet mass and cecum wet mass did not differ between $\mathrm{Ho}$ and $\mathrm{Ht}$ males. Regression showed that body mass only influenced

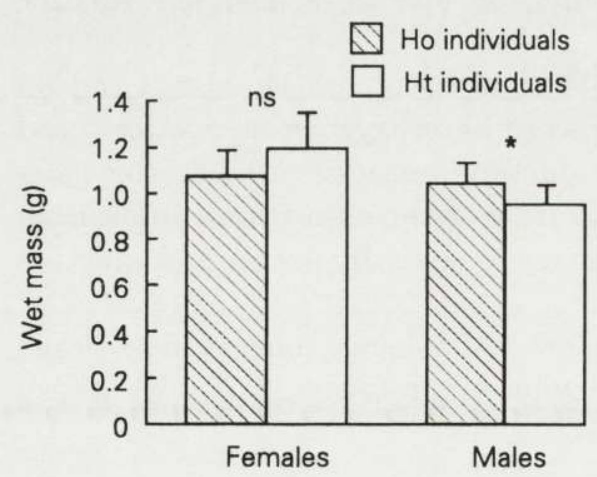

Fig. 2. Liver wet mass of Apodemus agrarius males and females. Significance levels in ANCOVA are given above the bars. Other explanations as in Fig. 1. 
large intestine wet mass of males $\left(R^{2}=0.26, p<0.0001\right)$. Likewise, in females, body mass was independent variable which affected stomach wet mass $\left(R^{2}=0.70\right.$, $p<0.0001)$ and the large intestine wet mass $\left(R^{2}=0.58, p<0.0001\right)$. There were no significant differences in the small intestine wet mass and cecum wet mass between $\mathrm{Ho}$ and $\mathrm{Ht}$ females ( $p>0.05$, ANCOVA). Liver wet mass was significantly greater in Ho than Ht males $\left(\mathrm{F}_{[1,45]}=4.37, p<0.05\right.$; Fig. 2$)$. However, in females liver mass did not differ significantly with heterozygosity $(\mathrm{F}[1,43]=0.91$, ns; Fig. 2).

The effect of heterozygosity on the serosal and the mucosal surface areas was not significant both in males and females ( $p>0.05$, ANCOVA). The lack of those differences appeared to be due to the lack of differences in the length and mass of the small intestine between Ho and Ht males and females.

\section{Discussion}

Apodemus agrarius is a species characterized by rather low genic variability (Britton-Davidian et al. 1991). In the population studied both the proportion of polymorphic loci $(\bar{P})$ and observed average heterozygosity $(\bar{H} o)$ seem to be slightly smaller than in some other populations of this species. Britton-Davidian et al. (1991) found $\bar{P}=10 \%$, while in our study $\bar{P}=5.3 \%$. When we include Pep-2 locus, $P$ reaches $7.7 \%$.

Average heterozygosity $\bar{H} o$ in the population studied is very similar to that found in a population from Greece $(H o=0.03)$, while in another A. agrarius population from Bulgaria $\mathrm{Ho}$ is clearly higher and equals 0.07 (Britton-Davidian et al. 1991). It seems probable that within its range the striped field mouse is divided into a number of partially isolated populations with slightly different genetic parameters.

Relationships between heterozygosity and individual characteristics may not always be detectable (Mitton and Grant 1984). The results of our study indicated that in wild Apodemus agrarius heterozygosity correlated only with a few of morphological parameters. It appears to be an effect of the low level of polymorphism based on the particular set of loci examined in the striped field mouse. In species with high genic variability (eg Peromyscus polionotus) low and high heterozygosity classes were clearly distinct (Teska et al. 1990). However, in our study $\mathrm{Ht}$ class of $A$. agrarius was heterogenous (individuals heterozygous at one, two or three loci studied) and geneticaly similar to Ho class (individuals homozygous at all the loci studied). Futhermore, we found relationships between heterozygosity and gut parameters only in males of $A$. agrarius. It seems that the great influence of pregnancy and lactation on gut parameters in females (Hammond and Diamond 1994, Hammond et al. 1994) may override a variability associated with heterozygosity.

The correlations between protein heterozygosity and individual parameters are detected with statistical methods and they are discovered more easily under some 
circumstances than others (Mitton and Grant 1984). We found that A. agrarius homozygous males had significantly greater liver wet mass than heterozygous males (cf Fig. 2). It is known that liver mass can change daily (Burrin et al. 1988) and because we did not take these changes into account the differences in liver mass of $A$. agrarius correlated with heterozygosity may not be reliable.

Mitton and Grant (1984) predicted that association between heterozygosity and fitness correlated characters should be more visible under stressful conditions. For example body mass in Peromyscus polionotus interacted with heterozygosity especially when animals were fed low-quality diet (Teska et al. 1990). On the other hand, the authors said that testing for correlates of heterozygosity under optimal conditions might fail to show important genetic effects. Therefore, in natural changing environmental conditions such as feeding habits, reproductive state, ambient temperature and photoperiod we did not find significant differences in body mass and small intestine parameters (length, wet mass, serosal and mucosal surface area) between $\mathrm{Ho}$ and Ht field mice. It seems that environmental stress did not influence those morphological characters of wild animals enough that differences associated with genic variability could be detected. However, in our study the length of the large intestine and cecum varied between heterozygosity groups and heterozygous males of $A$. agrarius had longer large intestines and ceca than their homozygous conterparts. Those attributes of heterozygous animals may be of importance when this ecologicaly variable species restructures its diet, turning to green food as a basic food item (Gębczyńska et al. 1987, 1989). Futher studies on this subject based on greater number of polymorphic loci and in heterogenous environment seem to be nessesary.

Acknowledgement: We would like to thank to Prof M. Gębczyński for his attention to our work and critical reading of the manuscript.

\section{References}

Borkowska A. 1995. Seasonal changes in gut morphology of the striped field mouse (Apodemus agrarius). Canadian Journal of Zoology 73: 1095-1099.

Britton-Davidian J., Vahdati M., Benmehdi F., Gross P., Nance V., Croset H., Guerassimov S. and Triantaphylliodis C. 1991. Genetic differentiation in four species of Apodemus from Southern Europe: A. sylvaticus, A. flavicollis, A. agrarius and A. mystacinus (Muridae, Rodentia). Zeitschrift für Säugetierkunde 56: 25-33.

Burrin D. G., Britton R. A. and Ferrel C. L. 1988. Visceral organ size and hepatocyte metabolic activity in fed and fasted rats. Journal of Nutrition 118: 1547-1552.

Cothran E. G., Chesser R. K., Smith M. H. and Johns P. E. 1987. Fat levels in female white-tailed deer during the breeding season and pregnancy. Journal of Mammalogy 68: 111-118.

Garten C. T., Jr 1977. Relationships between exploratory behavior and genic heterozygosity in the oldfield mouse. Animal Behaviour 25: 328-332.

Gębczyńska Z., Gębczyński M., Morzuch K. and Zielińska D. M. 1989. Food eaten by four species of rodents in polluted forests. Acta Theriologica 34: 465-477.

Gębczyńska Z., Sołtys H. and Sienkiewicz M. 1987. Food composition in striped field mice living at localities of various degrees of urban development. Acta Theriologica 32: 325-330. 
Green D. A. and Millar J. S. 1987. Changes in gut dimensions and capacity of Peromyscus maniculatus relative to diet quality and energy needs. Canadian Journal of Zoology 65: 2159-2162.

Hammond K. A. and Diamond J. 1994. Limits to dietary nutrient intake and intestinal nutrient uptake in lactating mice. Physiological Zoology 67: 228-303.

Hammond K. A., Konarzewski M., Torres R. M. and Diamond J. 1994. Metabolic ceilings under a combination of peak energy demands. Physiological Zoology 67: 1479-1506.

Harris H. and Hopkinson D. A. 1976. Handbook of enzyme electrophoresis in human genetics. Elsevier/North Holland, Amsterdam: 1-318.

Hartl G. B., Suchentrunk F., Willing R., Markowski J. and Ansorge H. 1992. Inconstancy of biochemical evolutionary rates affecting allozyme divergence within the genus Apodemus (Muridae: Mammalia). Biochemical Systematics and Ecology 20: 353-372.

Holišova V. 1967. The food of Apodemus agrarius (Pall.). Zoologické Listy 16: 1-14.

Leigh Brown A. J. 1977. Physiological correlates of an enzyme polymorphism. Nature 269: 803.

Mitton J. B., Carey C. and Kocher T. D. 1986. The relation of enzyme heterozygosity to standard and active oxygen consumption and body size of tiger salamanders, Ambystoma tigrinum. Physiological Zoology 59: 574-582.

Mitton J. B. and Grant M. C. 1984. Associations among protein heterozygosity, growth rate, and developmental homeostasis. Annual Review of Ecology and Systematics. 15: 479-499.

Nei M. 1978. Estimation of average heterozygosity and genic distance from a small number of individuals. Genetics 89: 583-590.

Quavi H. and Kit S. 1980. Electrophoretic patterns of aminoacylase-1 (ACY-1) activity. Biochemical Genetics 18: 669-679.

Selander R. K., Smith M. H., Yang S. Y., Johnson W. E. and Gentry J. B. 1971. Biochemical polymorphism and systematics in the genus Peromyscus. I. Variation in the oldfield mouse (Peromyscus polionotus). Studies in Genetics VI, The University of Texas Publication 7103: 49-90.

Teska W. R., Smith M. H. and Novak J. M. 1990. Food quality, heterozygosity, and fitness correlates in Peromyscus polionotus. Evolution 44: 1318-1325.

Zar J. H. 1984. Biostatistical analysis. Prentice-Hall, Inc. Englewood Cliffs, New Jork: 1-718.

Received 10 September 1995, accepted 20 August 1996. 
Appendix. List of enzymes, number of genetic loci and allele frequencies found in Apodemus agrarius (NE Poland).

\begin{tabular}{|c|c|c|c|c|}
\hline Enzyme name (abbreviation) & $\begin{array}{l}\text { E.C. } \\
\text { number }\end{array}$ & Locus & Allele & $\begin{array}{c}\text { Allele } \\
\text { frequencies }\end{array}$ \\
\hline Alcohol dehydrogenase (ADH) & 1.1.1.1 & 1 & A & 1.000 \\
\hline Albumin (ALB) & - & 1 & A & 1.000 \\
\hline Aldolase (ALD) & 4.1.2.13 & 1 & A & 1.000 \\
\hline Aminoacylase (ACY) & 3.5.1.14 & 1 & $\begin{array}{l}\mathrm{A} \\
\mathrm{B}\end{array}$ & $\begin{array}{l}0.638 \\
0.362\end{array}$ \\
\hline Carbonate dehydratase (CA) & 4.2.1.1 & $\begin{array}{l}1 \\
2\end{array}$ & $\begin{array}{l}\mathrm{A} \\
\mathrm{A}\end{array}$ & $\begin{array}{l}1.000 \\
1.000\end{array}$ \\
\hline Catalase (CAT) & 1.11.1.6 & 1 & A & 1.000 \\
\hline Cholinesterase (ChE) & 3.1.1.8 & 1 & A & 1.000 \\
\hline Esterase (EST) & 3.1.1.1 & $\begin{array}{l}1 \\
3\end{array}$ & $\begin{array}{l}\text { A } \\
\text { A }\end{array}$ & $\begin{array}{l}1.000 \\
1.000\end{array}$ \\
\hline Esterase-D(UV) (EST-D) & 3.1.1.1 & 1 & $\begin{array}{l}\text { A } \\
\text { B } \\
\text { C }\end{array}$ & $\begin{array}{l}0.021 \\
0.894 \\
0.085\end{array}$ \\
\hline Glucose dehydrogenase (GLDH) & 1.1.1.47 & 1 & A & 1.000 \\
\hline Glucose-6-phosphate dehydrogenase (G6PD) & 1.1.1.49 & 1 & A & 1.000 \\
\hline Glutamate-oxaloacetate transaminase (GOT) & 2.6.1.11 & $\begin{array}{l}1 \\
2\end{array}$ & $\begin{array}{l}\mathrm{A} \\
\mathrm{A}\end{array}$ & $\begin{array}{l}1.000 \\
1.000\end{array}$ \\
\hline$\alpha$-Glycero-3-phosphate dehydrogenase ( $\alpha$ GPD) & 1.1.1.8 & $\begin{array}{l}1 \\
2\end{array}$ & $\begin{array}{l}\mathrm{A} \\
\mathrm{A}\end{array}$ & $\begin{array}{l}1.000 \\
1.000\end{array}$ \\
\hline$\beta$-Glycerol-3-phosphate dehydrogenase ( $\beta$ GPD) & 1.1.1.8 & 2 & A & 1.000 \\
\hline Isocitrate dehydrogenase (IDH) & 1.1.1.42 & $\begin{array}{l}1 \\
2\end{array}$ & $\begin{array}{l}\mathrm{A} \\
\mathrm{A}\end{array}$ & $\begin{array}{l}1.000 \\
1.000\end{array}$ \\
\hline Lactate dehydrogenase (LDH) & 1.1.1.27 & $\begin{array}{l}1 \\
2\end{array}$ & $\begin{array}{l}\text { A } \\
\text { A }\end{array}$ & $\begin{array}{l}1.000 \\
1.000\end{array}$ \\
\hline Leucine amino peptidase (LAP) & 3.4.11.1 & 1 & A & 1.000 \\
\hline Malate dehydrogenase (MDH) & 1.1.1.37 & $\begin{array}{l}1 \\
2\end{array}$ & $\begin{array}{l}\text { A } \\
\text { A } \\
\text { B }\end{array}$ & $\begin{array}{l}1.000 \\
0.048 \\
0.952\end{array}$ \\
\hline Malic enzyme (ME) & 1.1.1.40 & $\begin{array}{l}1 \\
2\end{array}$ & $\begin{array}{l}\mathrm{A} \\
\mathrm{A}\end{array}$ & $\begin{array}{l}1.000 \\
1.000\end{array}$ \\
\hline \multirow[t]{2}{*}{ Peptidase (PEP) } & 3.4 .11 & $\begin{array}{l}1 \\
2\end{array}$ & \multicolumn{2}{|c|}{ unscorable } \\
\hline & & 3 & A & 1.000 \\
\hline Phosphoglucomutase (PGM) & 2.7.5.1 & 1 & $\begin{array}{l}\text { A } \\
\text { B }\end{array}$ & $\begin{array}{l}0.032 \\
0.968\end{array}$ \\
\hline 6-Phosphogluconate dehydrogenase (6PGD) & 1.1.1.44 & 1 & A & 1.000 \\
\hline Poshoglucose isomerase (PGI) & 5.3.1.9 & 1 & $\begin{array}{l}\text { A } \\
\text { B }\end{array}$ & $\begin{array}{l}0.995 \\
0.005\end{array}$ \\
\hline Protein (PROT) & - & 1 & A & 1.000 \\
\hline Sorbitol dehydrogenase (SDH) & 1.1.1.14 & 1 & $\begin{array}{l}\text { A } \\
\text { B }\end{array}$ & $\begin{array}{l}0.995 \\
0.005\end{array}$ \\
\hline Superoxide dismutase (SOD) & 1.15.1.1 & $\begin{array}{l}1 \\
2\end{array}$ & $\begin{array}{l}\mathrm{A} \\
\mathrm{A}\end{array}$ & $\begin{array}{l}1.000 \\
1.000\end{array}$ \\
\hline Transferrin (TRF) & - & 1 & $\begin{array}{l}\mathrm{A} \\
\mathrm{B}\end{array}$ & $\begin{array}{l}0.994 \\
0.006\end{array}$ \\
\hline Xanthine dehydrogenase (XDH) & 1.2.3.2 & 1 & A & 1.000 \\
\hline
\end{tabular}

